\title{
How can clinical pharmacy profession be used at the emergency wards?
}

\author{
Susie Vand, Inge Hermansen \\ From 4th Danish Emergency Medicine Conference \\ Roskilde, Denmark. 25-26 November 2011
}

\section{Background}

The aim was to reduce medication errors at the hospital and thereby increase patients' safety.

Hospital admission and discharge involve a high risk of medication errors, caused by unclear division of responsibilities, lack of communication, frequent exchange of synonyms and analogues, drugs, poly-pharmacy, compliance issues as well as insufficient education and training of the staff.

The pharmacist writes the interventions in the electronic patient record after admission to the medical ward.

\section{Methods}

During 3 month all interventions of the pharmacist were registered. 3 days after making the remarks the pharmacist registered the physician following up. The remarks were arranged in 13 categories for example doses, duplicate prescription, adverse effects, interaction etc. The interventions were registered as accepted, not accepted or no comment.

\section{Results}

The pharmacist checked the journals of 349 patients. Interventions were made on 188 patients corresponding to $54 \%$. The pharmacist wrote 315 interventions for the 188 patients.

The majority of the interventions were dealt with dose (18\%), additional treatment suggested (17\%), technical problems using the electronic patient record (14\%) and inadequate prescription (11\%).

Physicians agreed to $51 \%$ of the interventions. $10 \%$ of the interventions were accepted and modified by a pharmacist. $4 \%$ was accepted but has not resulted in an action. This means that there was action on $65 \%$ of all interventions.

* Correspondence: susivand@rm.dk Hospital Pharmacy, Aarhus, Denmark
The follow up remarks regarding duration of treatment and duplicate prescriptions were about $70 \%$. The follow up of inadequate prescription was $63 \%$ while the follow up for suggested additional treatment and remarks regarding the electronic patients' records were $58 \%$.

\section{Conclusion}

Written remarks from pharmacists can be used in the assessment of medication of patients in order to increase the general quality. It can be used as an assisting in optimizing medication treatment for admitted patients.

$65 \%$ of all interventions are followed up by a physician means a reduction of any possible drug-related problems.

Published: 16 April 2012

doi:10.1186/1757-7241-20-S2-P25

Cite this article as: Vand and Hermansen: How can clinical pharmacy profession be used at the emergency wards? Scandinavian Journal of

Trauma, Resuscitation and Emergency Medicine 2012 20(Suppl 2):P25.

Submit your next manuscript to BioMed Central and take full advantage of:

- Convenient online submission

- Thorough peer review

- No space constraints or color figure charges

- Immediate publication on acceptance

- Inclusion in PubMed, CAS, Scopus and Google Scholar

- Research which is freely available for redistribution 